\title{
An Analysis of the Application of Servant-leadership Model in the Educational Development Programmes of Selected Non-Governmental Organizations in Zimbabwe
}

\author{
Tomson Dube, Whitehead Zikhali, Sithobile Priscilla Dube \\ National University of Science and Technology \\ Zimbabwe
}

\begin{abstract}
Non-Governmental Organizations' (NGOs) unparalleled development education has a long tradition of educating the worker to make better development workers. The focus of this paper was to explore the application of servant-leadership model by NGOs, namely, those in selected areas of western region in Zimbabwe. The purpose of this paper is to analyse the effects of NGO leaders' servant leadership style on communities they serve through their development programmes as articulated by Robert $K$ Greenleaf. The population of the study consists of 12 NGOs. 105 respondents from the total population participated in the study. In analysis of data, all the primary data collected was analysed using Statistical Package for Social Sciences Version 20 and the usage of the NVivo version 11 for Key Informants. Cross tabulations were done to examine the difference in respondents' views of leadership as a function of age, level of education and the participant's category. The study concludes that one of the arenas where the least voicing of servantleadership has been in the political, government sphere. The energy around servant-leadership has focused around businesses, health care, higher education, schools, and faith-based institutions. A leadership model is presented as a contribution to the body of knowledge.
\end{abstract}

\section{Introduction}

The Research Paper is extracted from the researcher's studentship research (work in progress of a $\mathrm{PhD}$ in Business Administration - Proposals for Future Research) on the title 'The application of the Servant Leadership Management Model by selected Non-Governmental Organizations in Zimbabwe: A case study of Western Region Non-Governmental Organizations in the Faculty of Commerce, National University of Science and Technology, Zimbabwe. The researcher has vast experience in experiential learning both as lecturer for twenty years and as manager in the non-governmental organizations for eighteen years dealing with issues of module development, lecturing, coordination and development of educational programs for rural grassroots and NGO workers. The researcher has coordinated working groups of NGOs in civic education, humanitarian issues and the coordination of Master of Science in Development Studies program at the National University of Science and Technology's Institute of Development Studies. This paper was influenced by the researcher's involvement in the management of NGOs as he administered educational programs and service provisions to beneficiaries in development work and other sectors of civil society among the Western Region NGOs based in Bulawayo, Zimbabwe.

\section{Background of the study}

Servant leadership is a relatively new generation of leadership that was initiated by Robert Greenleaf in the 1970s. Greenleaf first used the term "Servant as a Leader" in his 1970 issue entitled "Servant Leader." Greenleaf developed the concept of servantleadership from the main figure Leo of Hermann Hesse's novel "Journey to the East." [14], [15], [22]. According to Greenleaf, putting the "servicing" mentality in the foreground is the most important direction of effective leadership [22].

According to Page and Wong, someone who is a servant leader is a person who works for the benefit of the organization and contributes to and serves the development and interests of followers to achieve organizational goals [18]. Drucker describes servantleader as a person who takes risks, serves, promotes occupations, supports rather than directs, and listens to others [18]. In Türkmen and Gül, [26] Blanchard et al [1] posit that servant-leadership is a concept of leadership that sees the interests of employees over the leader's personal interests [9], a new leadership model that prioritizes serving its followers [22], is a form of special leadership that makes organizations more workable.

The researcher observed how NGO leaders provide leadership in their institutions which led to an inquiry in the way Chief Executive Officers (CEOs) applied their chosen leadership style. Servantleadership was observed as the leadership style used by the selected NGOs. The results of the study on the selected NGOs [western region of Zimbabwe] indicate that servant-leadership is applicable in NGOs 
and has proved to be an effective strategy for innovation and wealth creation. Throughout this presentation, the people who engage in leadership will be called leaders and those toward whom leadership is directed will be called followers. Both leaders and followers are involved together in the leadership process. Northouse [15] states that "Leaders need followers and followers need leaders."

The definition of leadership that appropriately guides this paper is understood to mean that leadership is a process whereby an individual influences a group of individuals to achieve a common goal [15], [8], [10], [4], [23]. Some models/styles of leadership such as the charismatic leadership, participative, situational, transactional, Ubuntu philosophy and the transformational (the quiet leader) were mentioned with no in-depth discussion as they are also seen as different theoretical approaches to leadership. This paper is informed by the servant-leadership theory's applicability to NGO leaders' work in Zimbabwe. Many NGOs' work ethics are entrenched in serving the most disadvantaged members of our communities. Yet servant leadership values everyone's involvement in community life because it is within a community that one fully experiences respect, trust, and individual strength.

\section{Materials and Methods}

The study chose to use three types of designs or approaches, which include qualitative, quantitative, and mixed methods. As posited by Creswell [3], the three approaches are not as discrete as they first appear. Qualitative and quantitative approaches should not be viewed as polar opposites or dichotomies; instead, they represent different ends on a continuum [13]. Neuman [12] posits the same when he says, 'the languages and orientations of the styles are mutually intelligible ... [although] ... it takes time and effort to understand both styles and see how they can be complementary' [12]. This paper however, tends to be more qualitative than quantitative by virtue of the use of mixed methods research which resides in the middle of this continuum as it incorporates elements of both qualitative and quantitative approaches. The study chose this method as it was conducted in natural settings rather than controlled ones and because this method assumes that humans use what they see, hear and feel to make meaning of social phenomena. The method also allows for a variety of data gathering techniques [11]. The research methods used enabled the study to gather qualitative data for the study.

\subsection{Research Design}

The study took the format of an exploratory research design. The knowledge of NGOs by the researcher influenced the purposive sampling procedure albeit without any bias. From a list of the NGOs affiliated to the National Associations for NGOs (NANGO), based in Matabeleland, the NGOs were purposively sampled. As a result, no lottery or hat sampling was done. Selected geographically NGOs of Private Voluntary Organizations (PVOs) and TRUSTs in Matabeleland whose mandate is serving communities through the provision of programmes of civic education, community development and rural grassroots development education. A cross section of sectors was considered; types of NGOs - disability, civic, human rights, humanitarian support and rural \& urban development. Ninety-six questionnaires were distributed, $10 \mathrm{Key}$ Informant Interviews (KIIs) held semi-structured interviews and 5 Thought Leaders were interviewed. As a result, character centred servant-led NGO Model for promoting leaders was redefined from the study findings. NGO leaders' level of adaptation of organizational culture and commitment is moderate and is found to be at a high level in those institutions that practice servant-leadership. NGO leaders' view on the applicability of servant leadership style does not differ according to the institution's culture but differs according to their funding patterns.

\subsection{Research methods}

The research paradigm is anti-positivism and the research approach is qualitative while the research methods used is a case study of NGOs. The qualitative approach was enhanced with the use of the questionnaire, semi-structured interviews, observations and document Analysis. In terms of time horizons, the study implemented a cross-sectional design. (that is, data on relevant variables was collected one time only from a variety of respondents, subjects, or phenomena). The research methods design is the convergent parallel as defined by Creswell \& Plano Clark [3].

\section{Ethical considerations}

The researcher requested for permission to conduct the study from the CEOs or the Chairperson of the NGOs' board. Upon acceptance, issues of privacy and confidentiality of the case NGOs and respondents were upheld through pseudonyms of institutions. Information was gathered based on written informed consent by respondents.

\section{Data analysis}

In the analysis of the data, two software packages were used to analyze the collected data in an interpretative approach: Software Package for Social Scientists (SPSS) version 20 was used, (-used to 
analyse the questionnaire). The collected data are classified according to the sub-themes and these are loaded in the SPSS programme. In the analysis of the data obtained in the research, descriptive statistical techniques such as percent, frequency, standard deviation, the INVivo version 11 were used. This provided recurrent themes and helped to interpret the interviews with Chief Executive Officers and Thought Leaders. These thought leaders were comparatively weighed against some of the most well-known advocates of servant-leadership that include Ken Blanchard, Stephen Covey, Peter Senge, M. Scott Peck, Margaret Wheatley, Ann McGee-Cooper \& Duane Trammell, Larry Spears, and Kent Keith [16].

\section{Discussion}

The discussion mainly focused on issues surrounding the application of servant-leadership in NGOs showing a departure from the conversional leadership styles used in corporations and institutions of higher learning. The dominant focus is on the applicability of servant-leadership in NGOs in addressing the issues of vision, employee morale, experiential learning, followers and the other facets of leadership in NGOs. Servant-leadership has become a strategic leadership style that allows everyone in the organization to have a say and contribute to decision -making processes. It is applicable in higher educational sectors, NGOs and institutions that put serving first before leadership. Servant-leadership is used throughout the world, notably its effective implementation as observed in the United States, parts of Asia and Africa where institutions are equipped with the necessary skills for growing their organizations. In other words, Servant leadership is a philosophy and set of practices that enriches the lives of individuals, builds better organizations and ultimately creates a more just and caring world.

The servant-leader is servant first... It begins with the natural feeling that one wants to serve, to serve first. Then conscious choice brings one to aspire to lead. That person is sharply different from one who is leader first, perhaps because of the need to assuage an unusual power drive or to acquire material possessions... The leader-first and the servant-first are two extreme types. Between them there are shadings and blends that are part of the infinite variety of human nature [7]. The difference manifests itself in the care taken by the servant-first to make sure that other people's highest priority needs are being served. The best test, and difficult to administer, is: Do those served grow as persons? Do they, while being served, become healthier, wiser, freer, more autonomous, more likely themselves to become servants? And, what is the effect on the least privileged in society? Will they benefit or at least not be further deprived?

Literature revealed that to be a servant-leader requires a mindset and other-orientation that some leaders simply are not wired for -- so that makes it a disadvantage in the minds of some. I find Greenleaf's definition exceptionally relevant to the work of NGO leaders. Are those served grow as persons? That seems to me to be a wonderful goal, not only in terms of the communities we serve, but also in terms of our workers on the programs and staff. We want to help people learn and grow. Greenleaf argued that colleges and universities were not preparing young people to lead. He noted that in the 1970s there were many on campuses who were against leadership, because they were concerned about the misuse of power by leaders. Greenleaf said that there are three kinds of power-coercive power, manipulative power, and persuasion. By persuasion, he meant a process that did not involve coercion or manipulation. For persuasive power to be effective, the institution must have a great dream. He said: ...Institutions function better when the idea, the dream, is to the fore, and the person, the leader, is seen as the servant of the idea. It is not ' $I$,' the ultimate leader that is moving this institution to greatness; it is the dream, the great idea...It is the idea that unites people in the common effort, not the charisma of the leader. It is the communicated faith of the leader in the dream that enlists dedicated support needed to move people toward accomplishment of the dream... Persuasion, as an art of leadership, is tenable because of the persuasive power in the dream itself [7].

The NGO leaders provide a good training environment for their workers in experiential learning for rural development. The NGOs' experiential learning approach to programming offers students a hands-on opportunity to learn about development in the field. It allows students to be freer and cause growth in their management of community development. Most students found themselves working in NGO environments without themselves having basic training in community development. The development training programmes offered by the NGOs provided the student-worker with practical skills to serve the communities first. Students directly apply the concepts and skills of field-based learning as discussed in the modules and offers language capabilities developed through both formal instruction and informal practice. As servant leaders the important area of studies is the background conveyed in the practical field experience by the students where they take the lead and allow being servants first. In addition, students have occasion to hone their skills in dealing with and learning from the unexpected, as well as accomplishing a major learning task in a challenging new environment. They get to experience and witness communities practicing ubuntu philosophy. It is in this environment when the qualities of a servant-leader must be able to consistently exhibit and include empathetic listening, self-awareness, emotional intelligence, commitment 
to building and developing people, and interpersonal communication skills [23].

Within the literature on leadership styles, Trastek et al. [24] argue that "servant leadership" is one of the best forms of leadership for health care because it focuses on the strengths, contributions and development of trust within the team, and serving the needs of patients. However, servant leaders lead in a "side-by-side" rather than top down fashion exemplifying qualities of integrity and professionalism, and they are skilled at visioning, strategizing, tactics, aligning resources, inspiring others, and executing plans. This style of leadership is different from a more "transactional," command and control type of top-down hierarchical leadership that has characterized NGOs in the past. Servant (or adaptive) leaders operate according to collective rather than individual interests. Through their deep commitment to the growth of people (employees and communities), they may be considered to be "heartcentred", managing by demonstrating qualities of empathy, awareness, persuasion, conceptualization, foresight, and stewardship, Northouse [16]. They lead by establishing systems of shared values and by creating opportunities to support empowerment and community-building. Under servant-leaders, workers may be intrinsically motivated to change by having these shared values. Finally, being concerned with the way things work "on the ground", these leaders are reality-focused rather than only being "big picture" or goal-focused.

Most of the NGO leaders see themselves as providing service primarily to the communities. This belief is corroborated in management literature by Bryant [2] when he says that a servant-leader focuses primarily on the growth and well-being of people and the communities to which they belong. While traditional leadership generally involves the accumulation and exercise of power by one at the "top of the pyramid," servant leadership is different. The servant-leader shares power, puts the needs of others first and helps people develop and perform as highly as possible.

Following the characteristics mentioned in Spears [23], a model was refined from Patterson's 2003 servant-leadership model. Patterson [19], [20] posits that being an autocratic, overly authoritative or controlling leader does not engender trust or develop people for expanded capacity. However, servant leadership has its detractors as revealed in literature where some constraints in the application of the servant leadership style were observed as posited by Wong \& Davey [18], who identify what they term the six common criticisms. These constraints may be overcome by gradually admitting the steps that needs to be taken in order to realize the benefits of servantleadership.

The study observed from the interviews with Thought Leaders that "sometimes it is tempting for managers who are genuinely excited about servantleadership to want to start of jump into implementation, without having done the personal work that is necessary" Spears [23]. The research results would show that servant-leadership begins with the individual and then once one has kind of a critical mass of individuals within an organization, it is also then possible for organizations to act as servant-led institutions.

\section{Results}

Key Informants, (KIs) CEOs and NGO managers in the management of these organisations were interviewed and the reasons in the gaps why over eighty percent $(80 \%)$ were unaware of the application of servant leadership were exposed. The study was conducted to explore how servant leadership is practiced at NGOs in the western regions of Zimbabwe. The study sought input from full-time staff within twelve NGOs with the primary aim of gaining a better understanding of whether or not servant-led development education ignite and encourage deep approaches to learning.

The study found out that servant-leadership's applicability was not only effective globally in areas where it was initially implemented such as American corporations and other companies as well as in the western world, it is also effectively applied more in Zimbabwean NGOs. The results show that servant leadership can be applied at all levels of management and in all types of the studied organizations. However, organizations should be careful to select employees who (a) are interested in building long term relationships with followers and (b) have strong ethics.

- The expositions of the theories like ubuntu and servant-leadership were used in highlighting the underlying causes of the limited and inadequate funding for nongovernmental organizations. The limits on the utility of these theoretical approaches were also pointed out as limiting factors to the implementation of servant-leadership.

- Servant Leadership has emerged as a viable alternative to the use of power and a practical way of implementing high moral and ethical standards in leadership.

- One hundred percent $(100 \%)$ of the NGOs interviewed, confirmed that servantleadership advocates for principles of good governance and ethical practice.

- Eighty percent $(80 \%)$ of the respondents pointed out that bad governance is a costly omission for NGOs' funding in a globalized world where competition for funding is very rife. 
- One hundred percent (100\%) of the NGOs' KIs confirmed that servant-led NGOs serve. There is no other leadership style that can reach the grassroots and the most vulnerable members of the community efficiently other than a servant leadership style.

- $\mathrm{KI}$ at [25] posits that "servant-leadership bases itself on the premise that leaders are servants first and leaders second. They depart from the traditional leadership style of dominating subordinates and telling them what to do, and rather empowers the subordinate and act proactively to inspire them to perform.

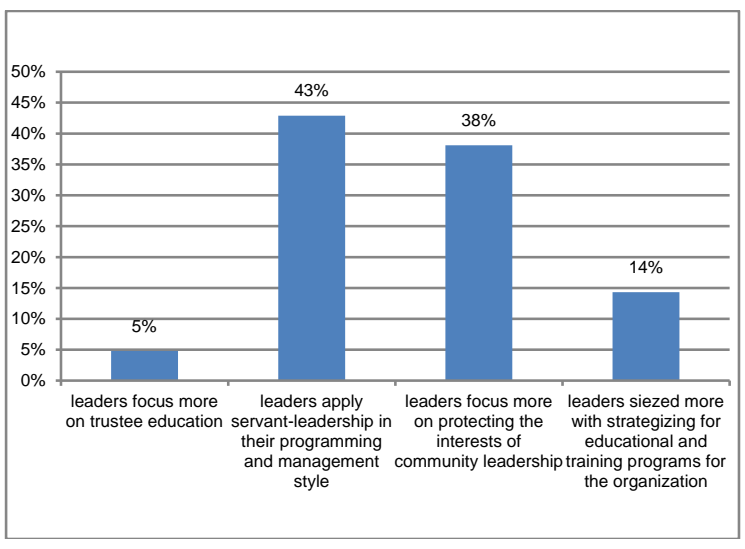

Figure 1. Applicability of Servant Leadership Model at the workplace

Literature corroborated the application of servantleadership with the findings in the study as observed in Spears' 1996 article where he cited the six major areas where the concept of servant-leadership can be applied. Figure 1 shows some of these which are enunciated as (a) trustee education, (b) community leadership, (c) experiential education, (d) personal and spiritual growth, and (e) education and training programs. The variables were crafted in such a way that the respondents would rate the variable according to their understanding of how NGOs apply the servant-leadership model. The variables are linked to the attributes of SL and best practices of a servantleader. Research findings from Figure 1 show that 43 percent of the respondents observe that leaders are seized more with strategizing for what is good for the organization in education and training programmes.

Figure 1., concurs with development trends in leadership styles where modern leaders remain competent to change their leadership style to suit the market-driven situation and work demands. This may mean that the time spent on strategising by leaders is a way to chat out the most applicable and suitable leadership style in their NGO. This may be subject to various interpretations although what seems to come out is that leaders are not complacent with the status quo. The 38 percent rating focus more on protecting the interests of the organization in their engagement with community leadership. Should it be assumed that servant-leadership is concerned with the employee, and that the 38 percent by the respondents confirms the growth of community leadership then at the heart of the organization is service! Servant-leadership includes the employees and community leadership in the decision-making process and empowers them to act, making servant-leadership a form of democratic leadership.

The study showed that a unique and flexible feature of modern leadership style in the changing world is that a leader rarely displays any one leadership style exclusively. In other ways, when a leader is seized in strategy, it could mean there are many ways or leadership styles employed in the strategy to realise a solution. For example, KI at [25] posits, "servant-leadership bases itself on the premise that leaders are servants first and leaders second." The five percent identified trustee education as important. Greenleaf [22] "urged trustees to ask themselves two central questions: 'Whom do you serve?' and, 'For what purpose?" With regards to community leadership, according to Spears [22], the number of community leaders using the Greenleaf Centre resources as a training tool is growing. This is buttressed by the $38 \%$ in Figure 1.

The study observed that concerning experiential education, experiential learning is a way of institutionalizing the practice of servant-leadership through the introduction and the reinforcement of this leadership approach to an organization [17]. The educational grassroots programs offered by the NGOs proved to be the core-business that has made NGOs relevant to communities. Page [17] also said: "When practiced regularly, these exercises are a means of overcoming the problem of people not applying what they have learned through servant leadership and leadership workshops and training" [17]. Page [17] identified a few common strategies wherein servantleadership is taught or ingrained in an organization. According to Page, the traditional method of experiential learning is through group exercises led by a facilitator, which usually requires one to four hours. Another method is the strategic placing of quotes in the workplace in order for the employees constantly to be reminded of the organization's goals and mission. E-mails, flyers, screen savers, and list serves are a few other strategies that can be used to ingrain to the workers the goals of the company.

Fourteen percent noted the importance of education and training programs. The implementation of servant-leadership programmes has been of late instituted in universities and colleges [22]. Before this development, NGOs used to train their staff on the job. In a case study done by Hardin, he found that students' perceptions of leadership changed in favour of servant-leadership after attending a servant- 
leadership workshop. He also found in this case study that the level of involvement or participation in the workshop about servant-leadership is correlated to how the students will eventually be receptive to the servant-leadership approach. The same practice was observed in the NGOs' education and training programs.

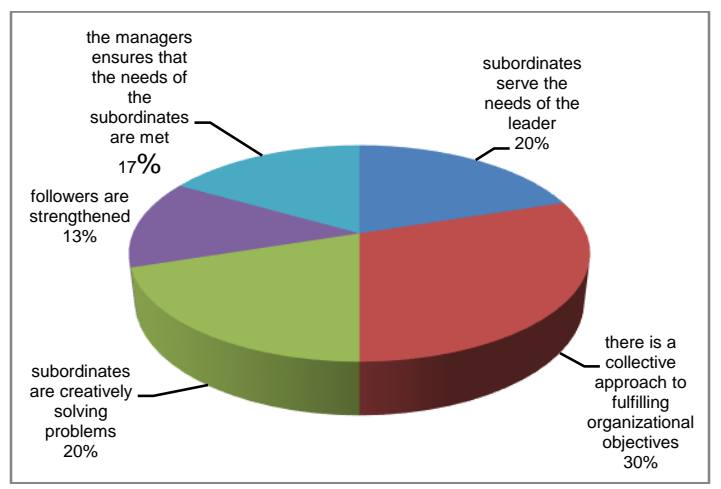

Figure 2. Application of Servant Leadership Model and its practice

Figure 2 shows a list of variables that apply to an organization in relation to the practice of servantleadership model as it relates to promote the application of servant leadership in local NGOs. Figure 2 shows that a leadership style can affect an employee's self-image in either a positive or negative way by being supportive, fair, and encouraging, or unsupportive, inconsistent, and critical. In addition, they can even affect an employee's health and energy level by creating a stimulating work climate or one filled with tension and fear. This could mean that the influence of a leader's style reaches greater proportions as the effects on individuals begin to have a cumulative effect on group performance. However, thirty percent in Figure 2 shows that there is a collective approach to fulfilling organizational objectives. As supported in literature, Warrick [27] notes that few leaders understand the full significance of how influential their leadership style is on the performance and satisfaction of their employees. Leaders control both interpersonal and material rewards and punishments that often shape employee behaviour and influence an employee's performance, motivation, and attitude.

Figure 3 shows the levels at which servant leadership is practiced in the participating NGOs in this study. It also shows the type of style in application. Respondents were asked which of the leadership styles in Figure 3 best described their organization's leadership style for which the percentages show the highest rating.

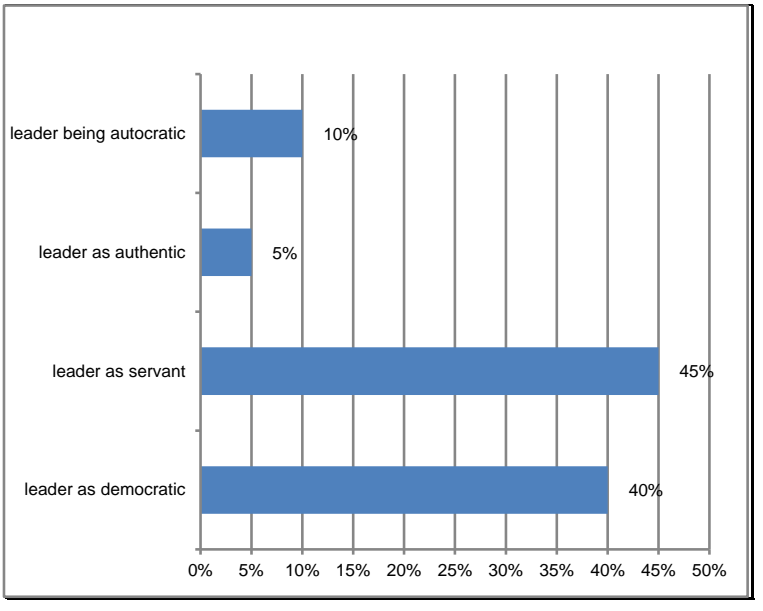

Figure 3. Applicability of Servant Leadership Style in the organization

Research results from Figure 3 shows that fortyfive percent of the respondents consent to the idea that servant leadership is practiced in the studied NGOs. This could mean that the respondents were able to distinguish servant-leadership from the other variables. It also could mean that servant leadership is prevalently practiced within their organizations. As supported in literature, the concept of servantleadership is gaining popularity among for-profit and not-for-profit companies, as well as in community leadership programs, formal leadership-management courses, independent consultants and in higher education. Some have compared this concept to turning the traditional hierarchical pyramid upsidedown so that in the minds of those formally at the top of the pyramid, the first priority will be the needs of his or her employees, customers or the community which he or she is serving [21].

Of the NGO leaders, 80 percent consent that servant-leadership is relational especially in NGOs whose work is serving the vulnerable grassroots communities. The KIs pointed out that their work is participatory in nature as a result building relationship is such a tall order to achieve. The same percentage (80 percent) agreed that servant-leaders are accessible since there is no hierarchy. A KI from NGO-FI, suggests that the CEO becomes part of the led and does not belong to some exclusive club. There is consultation in decision-making. Comparatively, NGO leaders, and college Principals are leaders in the school who play a key role in initiating, implementing, and sustaining outstanding schools. For example, as observed by Kasun [6], "Principals are responsible to a variety of stakeholders: students, teaching staff, support staff, parents, district authorities, the school board, and the community at large." Similarly, NGO leaders take the lead to serve the workers, community members and district 
authorities in the areas they implement their programmes.

Finally, the study noted that servant-leadership plays a pivotal role in the administration of NGOs' work. A model, with seven variables was refined for this paper. The model shows important tools for the credibility of servant-led NGO leaders in Zimbabwe. The refined model from Peterson's 2003 model has been instrumental in understanding the application of servant leadership in an NGO environment in Zimbabwe. The model has been refined for this paper as seen in a fuller explanation of the model in Figure 4.

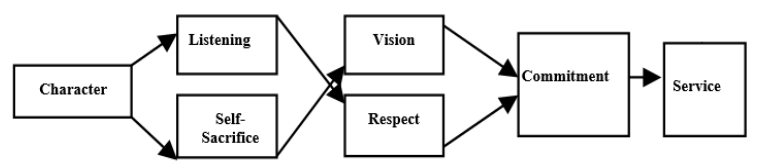

Figure 4. TD's Refined Leadership Model for Servant-Led NGOs in Zimbabwe

It became possible to refine and reconstruct a model based on seven variables found in the 12 researched NGOs in Zimbabwe. These variables comprise of the following: character, listening, selfsacrifice, vision, respect, commitment and service. The seven variables form a summary of the findings and contribution to the body of knowledge in this paper. In constructing these variables, the researcher realised that NGOs in Zimbabwe attract financial support due to the application of these variables as typical of servant-led NGOs. There was a unanimity among the 12 participating NGO leaders in this paper that the character of a leader is so integral to the institution. The character of the servant-leader can make or break an organization. The refined model in Figure 4 is anticipating that character yields better service. This study found that the lack of character by some NGO leaders caused serious challenges in the management of the organization. Yet a servant leader makes insightful, ethical and principle-centred decisions. S/he is honest, trustworthy, authentic and humble. The model reveals and speaks into the leader who is led with conscience and not led by ego. A leader filled with a depth of spirit and enthusiasm. The character is the backbone, the binding matrix or the very nerve centre of a person. In the African perspective, ubuntu/unhu (the Shona language - one of the major languages in Zimbabwe) is commonly translated 'humanness.' This ubuntu philosophy parallels servant-leadership philosophy. Above all, is committed to the desire to serve something beyond self. At the end of it, all leadership development is character development.

\section{Conclusion}

The servant-leadership philosophy and practices have been expressed in many ways and applied in many contexts. NGOs have become service centres of learning. This generally includes a learning component. Learning about serving and leading and similar ideas is part of what is intended through NGOs' service-learning programmes. So, in both international development, and in education, there is a real growth around servant-leadership which is greatly encouraging. The following conclusions were arrived at as key contributions to the body of knowledge in this paper.

- For the NGOs, the positive attitudes in African leadership like those of ubuntu philosophy need to be integrated with models of servant-leadership to come up with a better-informed and democratic model similar to the one refined for this study- suited for NGOs.

- For NGO leaders, servant-leaders have a tendency to grow others at their own expense. A new paradigm of leadership training should be developed and inculcated. For example, the spirit of the leader as a servant and the humanness of ubuntu may be what are needed to implement a strengths-based paradigm in NGOs.

- In view of leadership challenges faced by many NGOs, solutions seem to lie with organizations choosing the leadership style they strongly identify with. However, character of a servant-leader prepares the NGO to a different leadership dimension in a globalized world.

- For the academia, the study focused mostly on the top stratum of the targeted organizations. Therefore, it is recommended that future studies should target even those who hold nonmanagement positions to see if they will offer a different perspective.

- For the academia, the study focused on 12 leaders, 84 senior managers, 9 thought leaders, and observations of the 12 servantled NGOs. With this purposive sampling, the study cannot be generalized as the limitation is to the few that were interviewed. In order to evince more implications of the construct of service, (servant-leadership), future studies should enlarge the sample size.

In the same vein as Robert Greenleaf cared about universities, and their role in preparing young people 
for future leadership, NGOs cares more for rural communities they serve. Greenleaf called upon universities to have great dreams, and urged leaders to serve those dreams, uniting their campus communities and supporters in building toward the future. The NGOs also provided experiential learning, community leadership, education and training programmes to empower both their workers and the community leaders. In all these efforts, my impression is that there has been a shift from community service to service learning to servantleadership. My simplistic understanding is that a community service project would be something like getting a group of community members to get involved in a community project say on a Thursday. That's a good thing in and of itself. However, if the community members are then asked to reflect on their experience, and share their ideas with other adjacent members of the community, they would be entering the realm of service learning. My own view is that it doesn't become servant-leadership until the community members themselves have to identify the needs of their community or surrounding community, and then organize people and resources to meet those needs. That is what communities were required to do in areas where the case study was carried. It requires taking the initiative and exercising leadership.

\section{Recommendations}

- Examining how the personal values of servant leaders differ from those of other leadership styles, such as transformational and democratic leadership styles.

- While there is currently no preferred measurement tool to assess the level of servant-leadership application particularly in the Zimbabwean NGO set up, several proxy measures could be utilized to determine whether aspects of servantleadership are dominant in the workplace.

- Future research may be conducted on the sustainability influences in servant-led institutions as the theory may have originated from the teachings of Jesus Christ (Mark 10:35 - whoever wants to be a leader among you must be your servant - NLT). It would be interesting to reassess the origins of this theory from a purely religious/spiritual solution perspective.

- Finally yet importantly, further research on SL may be carried out in the area of voicing and application of servantleadership by people in elected office in the political, government sphere and the realm of public service.

\section{Recommendations for further Research}

Finally, in response to the application of servant leadership in NGOs, this paper suggests that NGOs apply servant leadership as a style in their institutions for their survival and sustainability. The researcher postulates that $u b u n t u$, leadership philosophy is quite rich with wisdom if practitioners are faithful to its principles. Servant and ubuntu leadership models resemble each other and have the potential of being jointly applied in organizations.

One of the underlying problems with servant leadership is the often-heard complaint, "I like the concept except for the word 'servant'. Do I have to be a "servant?"

The findings in this study and the existing literature led to the refinement of seven attributes of servant -leadership of which four are functional (character, vision, respect and service) and three accompanying attributes (mainly listening, selfsacrifice and commitment). These attributes constitute the foundation for a model of servantleadership refined and reconstructed for this paper.

\section{References}

[1] Blanchard, K., Leadership and High Performance Institutions Blanchard Approach in Creation. (Trans.) Uçtum, F. Istanbul: Kaizen, Resital Publishing. 2007

[2] Bryant, P., (2016). Servant Leadership: Theory \& Practice Volume 3, Issue 1, 9-11 February 2016 D. Abbott Turner College of Business. Available: https://csuepress .columbu sstate.edu/sltp/ [Accessed: 22/08/2017]

[3] Creswell, J. W. and Plano Clark, V., (2011). Designing and Conducting mixed Methods research, Thousand Oaks, CA: Sage.

[4] Damazio, F., (1988). The making of a leader. City Bible Publishing, Portland, Oregon.

[5] Hardin, F., (2003). Impacting Texas public schools through a student servant-leadership model: A case study (Unpublished doctoral dissertation). Indiana State University, Terre Haute.

[6] Kasun, R., (2009). "The Application of Servant Leadership by Selected New Jersey Public School Principals" Seton Hall University Dissertations and Theses (ETDs). 1504. Available: <http://scholarship. shu.edu/dissertations/1504> [Accessed: 03/08/2017]

[7] Keith, K. M., (2010). Servant Leadership in Higher Education: Issues and Concerns, [Online] Greenleaf Center for Servant Leadership, Palm Beach Atlantic University Palm Beach, Florida, March 18. Available: $<$ toservefirst.com /pdfs/Servant-Leadership -in-HigherEducation.pdf $>$ [Accessed: 16/07/2017] 
[8] Kouzes J. M. \& Posner B. Z., (2007). 'The Leadership Challenge 4th Ed.’ August. San Francisco: Jossey-Bass.

[9] Laub, J., (1999). Defining Servant Leadership: A Recommended Typology For Servant Leadership Studies. Servant Leadership Research Roundtable, The School of Leadership Studies, Regent University.

[10] Maxwell, J. C., (2003), The 4 Pillars of Leadership, Tennessee, Struik Christian Books.

[11] Neuman, W. L., (2000). Social Research Methods: Qualitative Approaches. Fourth edition. Allyn and Bacon, Boston, Massachusetts.

[12] Neuman, W.L., (2003). Social Research Methods: Quantitative and Qualitative Approaches, Fifth edition. Allyn and Bacon. Boston. Massachusetts.

[13] Newman, I. \& Benz, C.R., 1998, QualitativeQuantitative Research Methodology_ Exploring the Interactive Continuum. Southern Illinois University Press.

[14] Northouse, P. G., (2004), Leadership: Theory and practice (3rd ed.). Thousand Oaks, CA: Sage Publications

[15] Northouse, P. G., (2007), Leadership Theory and Practice. (4th ed.). Thousand Oaks, CA: Sage Publications.

[16] Northouse, P. G., (2012), Leadership: Theory and practice (6th ed.). Thousand Oaks, CA: Sage Publications.

[17] Page, D., (2004), Experiential learning for servant leadership.Retrieved from: http://www.regent.edu/ac ad /global/publications/sl_proceedings/home.cfm

[18] Page, D., \& Wong, P. T. P., (2000). A Conceptual Framework for Measuring Servant-Leadership. Trinity Western University, Langley, B. C.

[19] Patterson, K., (2003), 'Servant Leadership: A theoretical model.'[Online] Servant Leadership Research Roundtable Proceedings. Available from: http://www.regent.edu/acad/global/publications/ slproceedings/home.shtml. [Accessed: 23/08/2017]

[20] Patterson, K., (2003). Servant Leadership: A Theoretical Model. Servant Leadership Research Roundtable, The School of Leadership Studies, Regent University, August.

[21] Russell, R. F., (2001). 'The Role of Values in Servant Leadership,'[Online] Leadership and Organization Development Journal, 22(2), pp.76-83, Available: http://emaj.pitt.Edu/ojs/index.php/emaj/article/download /21/131Sajjad [Accessed 21/07/2017]

[22] Spears, L. C., (1996). Reflections On Robert K. Greenleaf And Servant Leadership. Leadership Organization Development Journal, 17(7), 33-35. 1996. https://doi.org/10.1108/0143 7739610148367 [Accessed: 22/07/2017]

[23] Spears, L. C. 'Character and Servant Leadership: Ten Characteristics of Effective, Caring Leaders. The Spears Center,' [Online] The Journal of Virtues and Leadership,
Vol. 1 Issue. 1, 2010, 25-30. (C) 2010 School of Global Leadership and Entrepreneurship, Regent University. Available from: https://www. regent.edu/acad/global/ publications/jvl/vol1iss1/Spears_Final.pdf [Accessed: 20’05/2018]

[24] Trastek, V.; Hamilton, N.W.; Niles, E.E. Leadership models in health care - A case for servant leadership.

[25] Mayo Clin. Proc. 2014, 89, 374-381.

[26] Türkmen, F., Gül, I., (2017). The Effects of Secondary School Administrators' Servant Leadership Behaviors on Teachers' Organizational Commitment [Online] Journal of Education and Training Studies, Vol. 5, No. 12; December.

[27] Warrick, D. D., (1996). 'Leadership Styles and Their Consequences:' [Online] Journal of Learning and Simulation (College of Business Administration, University of Colorado, Colorado Springs, CO 80908.) Available from: https://eric.ed.gov/?id= EJ265922 [Accessed: 20/09/2016] 